\title{
Investigating effectiveness of clandestine advertisement and organizational strategy in brand management
}

\author{
M. R. Shojaei ${ }^{a}$, Sh. Sabaghi ${ }^{b^{*}}$ and N. Shirdel ${ }^{b}$
}

${ }^{a}$ Assist. Prof. \& Faculty Member, Department of Accounting, Shahid Beheshti University, Tehran, Iran

${ }^{b}$ Postgraduate Student, Business Administration, Ershad university, Damavand, Iran

\section{H R O N I C L E}

Article history:

Received June 4, 2014

Accepted 2 November 2014

Available online

November 102014

Clandestine advertisement

Organizational strategy

Brand management

Bank

\section{A B S T R A C T}

This investigation tries to examine correlation between clandestine advertisement and organizational strategy in brand management via available sources and by using a field study. In fact, it intends to raise the question "Are clandestine advertisement and organizational strategy effective in management of products brands?" This is an applied and descriptiveapproaching study. The study chooses a sample of 171 regular customers who do their day-today banking business activities through an Iranian bank named Sepah bank in city of Tehran, Iran. Using structural equation modeling, the study confirms a positive and meaningful relationship between clandestine advertisement and organizational strategy in brand management.

\section{Introduction}

Today, there are problems faced by marketing managers: their efforts to create and maintain a brand without required planning, and lack of knowing characteristics of trade names and proper methods of management of brand cannot integrate a product and its trade name, effectively. Majority of marketing managers and/or brand managers know marketing concepts such as identifying customer's needs, positioning, promotional and advertising activities, and they have sufficient experience to handle different issues. However, they cannot employ marketing concepts in promoting a brand value. These are consequences of lack of good knowledge of trade name as one of the most important clandestine assets of a company and their understanding of asset include visible and touchable things. Organization management may help managers of manufacturing enterprises use managerial tools like targeting, planning, coordination, mobilization of resources and facilities and control to achieve organization's goals. The science of brand management enables managers to plan correctly in line with fulfilling objectives to maximize an achievement without wasting resources. Having a strong brand opens route to a successful in research and development activities and directs organizational 
ideas about future of activities and creativities to a business value creation perspective (Keller et al., 2011).

Competition expands extremely rapidly, and today, organizations wish to access information. Clandestine advertisement in marketing has already considered, increasingly. Therefore, conscious presentation and positioning various branded products in movie pictures, television footages and pictorial books, and other examples in news networks, poetry and music, books, computer-aided and video games, Internet, cartoon and animation films and sports have integrated product and media called clandestine or insensible advertisement.

On the other hand, in discussion about organization strategic management, although strategic plans of organizations are founded by specialists and strategists, but in implementation step, it involves necessity of top management's cooperation and companionship. In different decision-making, execution and evaluation stages, organizations are also to take a cultural strategy in order to maintain an outer adjustment and inner coherence of their goals (Molkaraei, 2013).

In this investigation, we attempt to study the existing references, to examine relationship between clandestine advertisement and organizational strategy in brand management and to provide a conceptual model in this respect. Finally, we wish to find out whether or not clandestine advertisement and type of organizational strategy are effective in management of products brands.

\section{Clandestine Advertisement}

Before defining clandestine advertisement, first, we define advertisement and its types:

It is a way of making communication between advertising messages and addressees, directly or indirectly. In direct advertisement, messages are disseminate frankly, openly and without intermediate, but, in indirect advertisement, they are published unclearly, clandestine, hinted and secretly (Moore, 1982).

\subsection{Direct Advertisement}

In this type of advertisement, messenger may expound and trumpet his message to addressees, but frankly and fearlessly. In this method, listeners and viewers receive a text or picture as an "advertising" message or announcement, and receivers are seen and known as an "advertiser" (Moore, 1982). The most significant advantage of a direct advertisement for receivers is its message of which they are aware of "advertising" nature of the direct message. Thus, they are not surprised and are free to accept or reject it subjectively (Ti-appey, 1996).

\subsection{Indirect Advertisement}

Indirect advertisement, sub-sensible or clandestine has no clear and open appearance and emerging. In indirect method, advertising goals of published messages are hidden and non-sensible. Level of being indirect in indirect advertisement is different, and depends on stakeholder's willingness and desire and skillfulness rendered for its designing. To prepare designs and plans of indirect advertisement, it is not simply possible to use all available means, and their preparations require cleverness, smartness, information and much experience, and there are factors, conditions and situations involve in to reach an achievement or failure (Zanot et al., 1983).

A characteristic of indirect advertisement is that its messages go through invisible, hidden and unexpected channels. Such advertisement does not follow or use certain and repetitive forms and formulations. However, in their making, expected opportunities, new situations and unanticipated events are mostly utilized (Theus, 1994). 


\section{Organizational Strategy}

Majority of organizations neglect the first step of comprehensive quality management, i.e. definition of strategic goals and integrating goals with presumptions of quality improvement. It is possible that sustainability of a process might make improvement considerably, but does not influence on health of organization yet. Therefore, strategic planning should bridge improvement of internal processes to priorities for supporting long term success of organization (Davenport \& Linder, 1994).

\subsection{Necessity of Strategic Goals in an Organization}

By looking at concept of strategic management deeply, we may find necessity of its usage. Due to environmental changes which, at present, taken more acceleration, and because of complexity of organizational decisions, necessity of applying a comprehensive plan to tackle problems is more sensible than before. Strategic management, depend on a dynamic, futuristic, comprehensive and appropriate subjectivity and is a solution for today's many organizational problems. Its foundation lays on a knowledge, which managers have about rival companies, prices, raw material suppliers, distributors, governments, debtors, shareholders and customers who are present all over the world. These factors are crucial elements of business success in today's world. Finally, strategic management is defined as environmental assessment (both internal and external environments), formulation of strategy, its implementation, evaluation and control. Hence, strategic management emphasizes on monitoring, and evaluation of opportunities and external threats under shadow of attending weaknesses and strengths of an organization. In other word, art and science of formulation, execution and assessment of decisions are multifunctional assignments enable organization to obtain its long term objectives. Then, one of most important tools organizations may use for fulfilling success in future will be "strategic management" (King et al., 1989).

We can point out to time of sanction as one of factors for using strategic objectives. Strategic Management provides possibility for economic units to shape their future activity and to prevent negative consequences of sanction, and to identify quickly solutions for this burden by signifying internal capabilities and taking extra organizational factors into account and to do appropriate action, proportionally. Analysis of intra organizational elements includes review of nationwide and international environmental factors resulting to determine opportunities and risks, which threat economic enterprises rom outside. Opportunities mean concept of desirable and important situations, and risks mean undesirable situations around economic units (Molkaraei, 2013).

\subsection{Advantages of Organization's Strategic Management}

Strategic management allows an organization to act in a creative and innovative method and treat somehow to shape its future actively. This method urges the organization to be initiative and influential by its activities (not react only to action), so to make its destiny and control its future. Historically, the main advantage of strategic management was to help organization use more regular, more reasonable and more logical procedures in order to choose roadmap and strategic alternatives and, by this, formulating better strategies. There is no doubt that it is one of advantages of strategic management; but study results show that this process could contribute an important role in it. Many manager and employees are committed to support their organizations by dealing with this process. Another important benefit of strategic management is that would bring more understanding and commitment in managers and staff. In strategic management, one major advantage is that it creates an opportunity for assigning responsibility to staff. By this, employees are encouraged to participate in decision-making processes, to practice bringing creativity, innovation and ambition and to increase their effectiveness (Henderson \& Venkatraman, 1993).

\subsection{Strategies of Whole Organization}

In order to determine the strategy of a whole company/organization, its perspectives and missions are to be considered, and long term goals are set and evaluate and choose those strategies to achieve 
success of the whole organization. In the field of business, by taking its outlook and mission in general and relevant external and internal factors, strategies are determined to enable it to reach its success in the field of competition. For functions, the same procedures are followed, as assigned by top management, for success of functional unit, in one hand, and related business unit of organization/holding company, in the other. Because of similarity of the whole company and its business scope (strategic trading unit), many categories of strategy, in both levels, are applicable (Henderson \& Venkatraman, 1993).

Strategies of any company/organization can be divided in the following groups:

- Directory strategy (targeting towards growth)

- Portfolio strategies: Portfolio analysis (coordinating cash flow of units or business)

- Supervisory strategies (creating aggregate through development and contribution of sources)

\section{Concept of Brand}

In this section, we review concept of a brand and its value:

A brand or trade name is normally a name, term, sign, design or combination of them for identification of products and/or services of seller (s) or supplier (s), and distinction of goods and services by those of competitors. Summarily, a trade name applies to know a sell or manufacturer. Brand can be another name, sign and a symbol (Keller et al., 2011).

\section{Brand Management}

Brand Management includes a promise, fulfilling promise and supporting it, accordingly and requires to be defined, properly. Brand management is art of creation and survival of a trade name (Jafar Pishe, 2011). In outset, brand management is equipped with full knowledge and understanding the term of trade name, and it includes a promise given to customer.

\section{Brand Strategy}

Strategy of a brand creates a special value for customer via providing a trade name with special identity and its promotion, which is not simply imitable by competitors. This strategy leads to an increasing benefit margin and more efficiency of investment. Cycle of a brand strategic planning is as follow (Keller et al., 2011):

\section{Business strategy}

\section{Brand expression}

\section{Marketing}

Today, neuromarketing and sub-sensible marketing gave a strength to advertisement companies to penetrate to individual's unconsciousness. In 2008, the study of a German research team revealed that brain make decisions unconsciously. They discovered it by observing unconscious activity of grey matter of brain a few seconds prior to conscious signals of decision-making. This experiment allows that an individual's chosen alternative predicted just 7 seconds before his/her conscious decisionmaking by brain signals (Ariely \& Berns, 2010). Using EEG tests for measuring brain signals, brain scans to test brain activity through variation of blood circulation, and technology of eye tracking in neuromarketing, developed the world of marketing and advertisement dramatically (Ariely \& Berns, 2010). An additional study on shipping habits determined 76 percent of American people decide to do shopping just in store, and cash payment represents their sudden shopping. Hence, shopping from shelves and marketing in a store is more important than ever (Ariely \& Berns, 2010). In a study, individuals were asked to put technology-aided eyeglasses to track eyes in store to pick up items for 
shopping. Finally, analysis of their eye movements, during shopping, indicated that it takes only 200 milliseconds one man decides to buy something; it is merely a blink. In other word, a "closenessavoidance" approach urges someone to choose between cookie and chocolate. Eyes track cookie for which buyer is eager to get, even though he/she does not decide to buy it. Interestingly, 20 percent of eye tracking is for something you are going to buy. During shopping, you see a pack of cookies, take it, put it aside and go away. Sometime, you come back and take it in your shopping basket (Ariely \& Berns, 2010). Marketing industry does not deal with something that individuals choose, but it pays attention to the situation before they go for shopping. Advertisement scrambles our attention and excitement bustles us. These two factors are predictors of our shopping (Ariely \& Berns, 2010).

In a research for evaluating interests in Hollywood movies, when 40 films were advertised to more than 1000 people, their pulses, breathing, sweating and movements were measured. Using these data, it was possible to anticipate weekly box office of films in a cinema. However, if a film did not extend its exciting for action to a specific threshold (65), it had $\$ 10,000,000$ income in first week. However, for a film with the threshold of 80 , it earned more than $\$ 20,000,000$ in first week. Now, Fox and Paramount studios exploit neuromarketing for this purpose. Recording brain's electric waves when encountering advertisement, one's memory, attention, consciousness and thought are activated. At the same time, edge of forehead which process exciting information, is activated (Ariely \& Berns, 2010). Many believe a neuromarketing study human's brain, but it should still settle contradictions and antagonism exist in it. For example, we may like an advertisement, which creates a positive excitement in people, but excitements and its subsequent association for buying a product may be inefficient.

\section{Theoretical Framework of Investigation}

\subsection{Brand Management}

Brand Awareness: This is associated with providing and shaping awareness of brand, influencing on consumers' mind and encouraging to give a super value to brand (Keller et al., 2011; Rossiter \& Percy, 1987). Consumers ought to be aware of brand first and then intend to do shopping. This awareness is the first stage for buyer to be prepared for development of priority of brand and approaching to the point of shopping (Ross \& Harradine, 2004). Brand awareness is consumer's ability to recognize a trade name under different circumstances (Keller et al., 2011). We can take and review this issue in the framework of brand recognition.

Brand Recognition: It is an initial observation. When consumers receive a signal, they recognize probably the brand, which has already seen before. They may identify many brands, but only remind a few ones; even sometimes, they remember only a single brand. Therefore, brand recognition involves a minimum awareness of it, and considers as an auxiliary for calling a brand (Radder \& Huang, 2008).

Brand Popularity: This term includes market leadership, inclination for more desirable evaluating and greater market share. Popularity is witnessed by giving a benefit to customer and creating his/her selfreliance to make decisions for shopping something. It can offer commitment and guarantee to buyers, especially, when evaluation of products characteristics for choices is not easily comparable (like car). Consumers may reduce risk by shopping known models of cars rather than unknown ones. More important, perceptive quality proportion to popularity can increase customer's satisfaction due to consumption experience. If brand popularity is able to provide little benefit for customers, they reciprocate the received benefit in terms of long loyalty to the brand, confirming effectiveness of marketing, developing company's competitive position and, at last, possibility for the company of more sales (Scherer \& Ross, 1990). 
Effectiveness criterion, because of Yash orbit in determining objectives and measuring results, has a long history in promotion, particularly, advertisement. For the first time, Lewis was the first author who wrote in his book of advertisement in 1898 a known method of four words attention, interest, demand and action in order to make advertisement effective. Since that criterion became one of basic discussions in advertisement.

Dutka and Colley (1995) gave the concept of DAGMAR (Defining Advertising Goals for Measured Advertising Results) in his book of advertisement. He drew up the main topics of a method, which still involves researchers in a series of processes to test effects of special of advertising and activities. He argued that the advertising goal is special communications.

Attitude: attitude towards a product or service would affect evaluation of effectiveness, since consumers are under their attitudinal affection when responding to an advertisement. Attitude toward advertisement influences on purpose of shopping intention and mental prerequisites of consumers from brand (Onkvisit \& Shaw, 2004). A consumer, who gets a positive attitude towards a company's brand, will gradually take a step to loyalty. This is a very important question and, perhaps to say, provides the greatest achievement for an advertisement (Onkvisit \& Shaw, 2004).

Brand Remembrance: This issue is the second level of awareness of a brand, and it is associated with a consumer's ability to revive a brand from his memory when presented by a corresponding signal (Ross \& Harradine, 2004).

Shopping Intention: Today, shopping intention reflects a consumer's foreseeable behavior in deciding to buy in future (for example, what product or brand is in next turn). It helps considerably to shape consumer's attitudes, so that shopping intention forms an attitudinal transfer pattern of next shopping (Espejel et al., 2008).

Brand Position: This status refers to certain information of a brand in consumers' memories categorically. This is because, particularities of positioning is that it includes only partial information of a brand. Memory, in this case, refers to sharing information (Anderson \& Bower, 2014). A strong brand position enables consumer to receive unique perceptions of brand and its intensity of influence and, thus, his/her findings of it influences on relationship between consumer and company in long term (Fournier, 1998). Consequently, the brand position can be effective on profits, cost-risk relation (Lee \& Liao, 2009). In addition, brand position depends on consumers' knowledge about important properties of product which itself enable them to define and compare with competitive products (Kotler, 1997).

\section{Organization Strategy}

Total strategies of a company/organization may be classified in three groups:

- Directory: targeting toward growth,

- Portfolio or Portfolio Analysis: coordination of cash flow of units or business,

- Supervisory: providing aggregation by developing and sharing resources.

\section{Research Hypotheses}

In this study, the following assumptions have drawn up to examine the subject-matter:

* Clandestine (non-sensible) advertisement affects the way of brand management,

* There is a meaningful relationship between organization strategy and brand management, 
* In strategy and clandestine advertisement, conceptual model of brand is meaningful.

\section{Research Methodology}

This study is based on a descriptive-approaching model in terms of objectivity and applicability points of view. In this study, we have used a library based (book, articles and internet texts) to identify and to recognize the literature and research variables. On the hand, we exploit a field study by disseminating a questionnaire among customers of Bank Sepah branches in Tehran Province, Iran. The study timing limit is limited to summer of 2014. The sample size is calculated as follows,

$$
N=Z_{\alpha / 2}^{2} \frac{p \times q}{e^{2}},
$$

where $N$ is the sample size, $p=1-q$ represents the probability, $z_{\alpha / 2}$ is CDF of normal distribution and finally $\varepsilon$ is the error term. For our study we assume $p=0.5, z_{\alpha / 2}=1.96$ and $e=0.05$, the number of sample size is calculated as $N=171$. In this study, for normalized increase, we used the following means:

1. Opinions of specialist professors,

2. Opinions of managers and management experts,

3. Review the articles, books and similar papers on the subject-matter.

In order to define stability of questionnaire, we used coefficient of Crombach's Alpha by the statistical SPSS software. We obtained this coefficient equal to 0.816 for this questionnaire; it is larger than standard number of 0.7 ; hence, it can be said that the questionnaire has a suitable normalization. Finally, data are analyzed at a perceptive level using LISREL software, copy 8.35. Investigation was made for the study hypothesis in this level using the structural equation modeling.

\section{Study Conceptual Model}

With regard to studies carried out in relevant books and literature in subject-matter, the following conceptual model seems appropriate for the study. Note that the model derived from a combination of other ones:

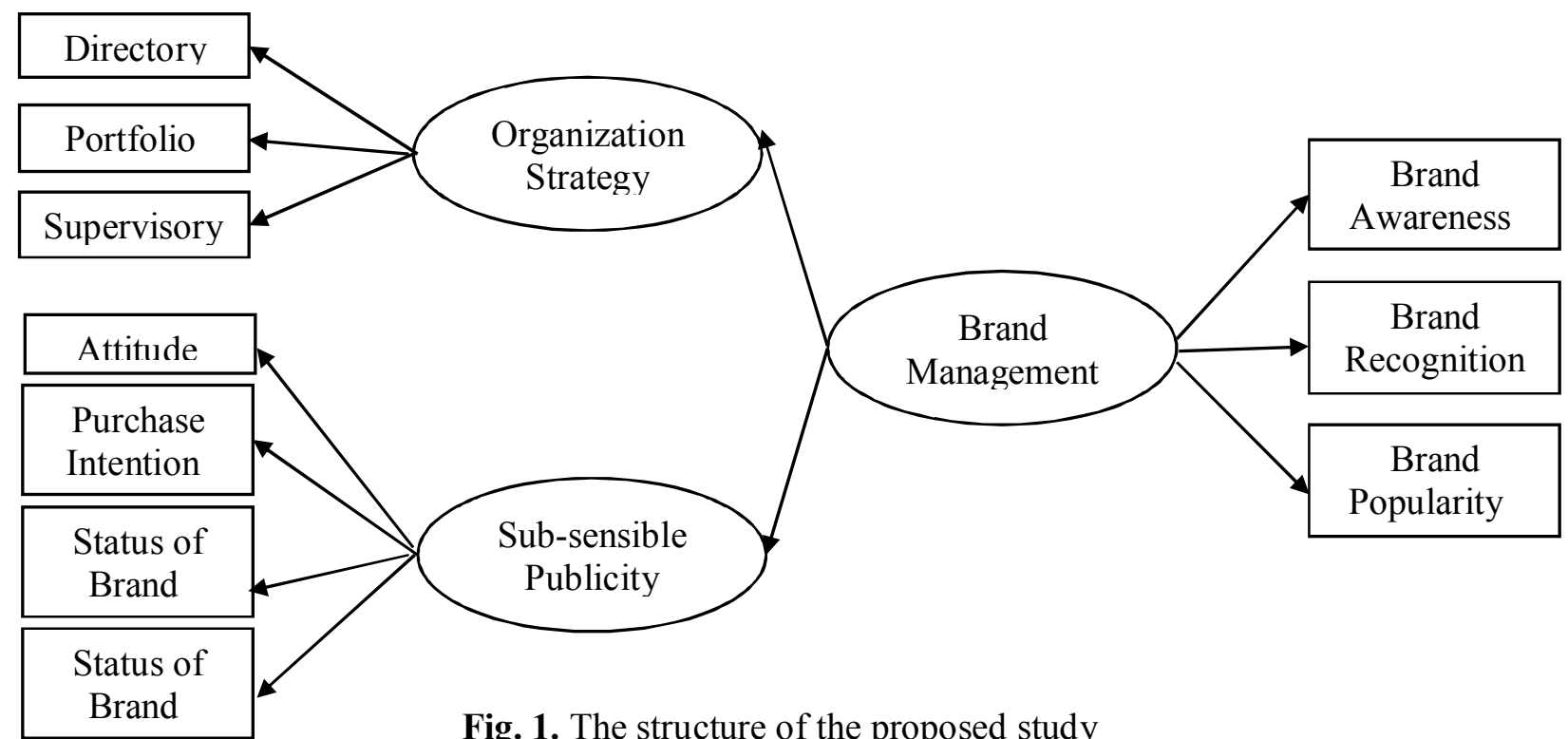

Fig. 1. The structure of the proposed study 


\section{Information Analysis}

In this section, we deal with information analysis using the statistical software in two parts. In the first part, SPSS is employed to examine frequency of information about participants; in the second, meaningfulness of the conceptual model is examined by LISREL.

\subsection{Personal characteristics of the participants}

In our survey, $55.6 \%$ of the participants were male and $44.4 \%$ of them were female. Fig. 2 shows other personal characteristics of the participants.

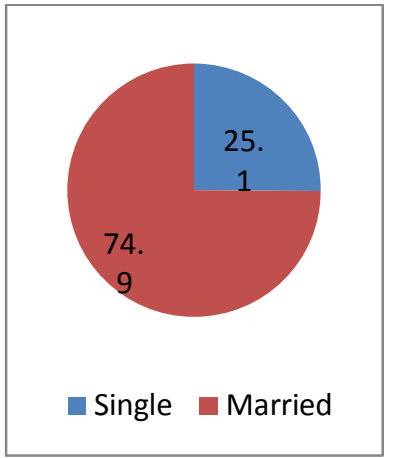

Marital status

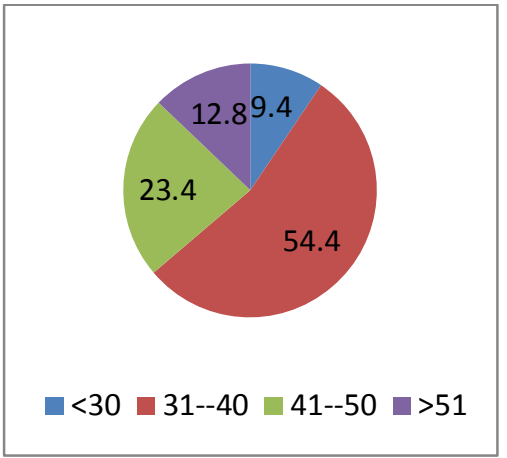

Age

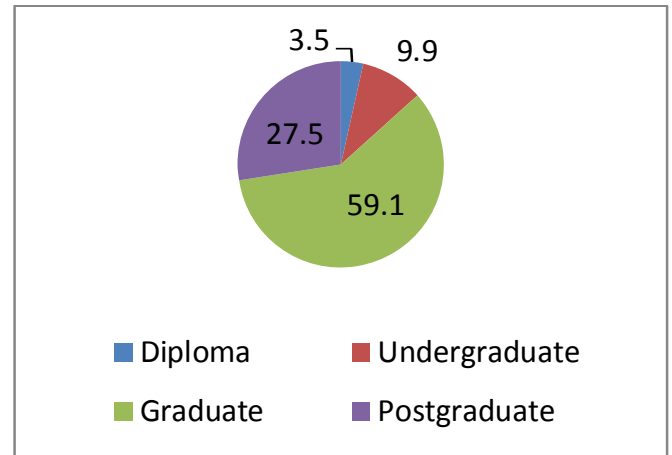

Education

Fig. 2. Personal characteristics of the participants

Fig. 2 shows that $74.9 \%$ of samples are married (128 individuals), and $25.1 \%$ single (43 individuals). In addition, $9.4 \%$ of samples are in the age less than 30 years, $54.4 \%$ ranged 31 and 40 years, $23.4 \%$ between 41 and 50 years, and 12.8\% older than 51 years. Finally, Fig. 2 shows that percentage distribution of frequency of participants based on their education. It indicated that 3.5\% (6 participants) hold high school diploma, 9.9\% (17 participants) undergraduates, 59.1\% (101) graduates and $27.5 \%$ (47) postgraduates. In the second part, we assess meaningfulness of the study conceptual model using the method of structural equations aided by LISREL software. Results of running this structural model appeared in Fig. 3. As we can observe, there is a relatively strong structural relationship between Brand management and organizational strategy $(\mathrm{R}=0.69)$, and also between brand management and sub-sensible advertisement.
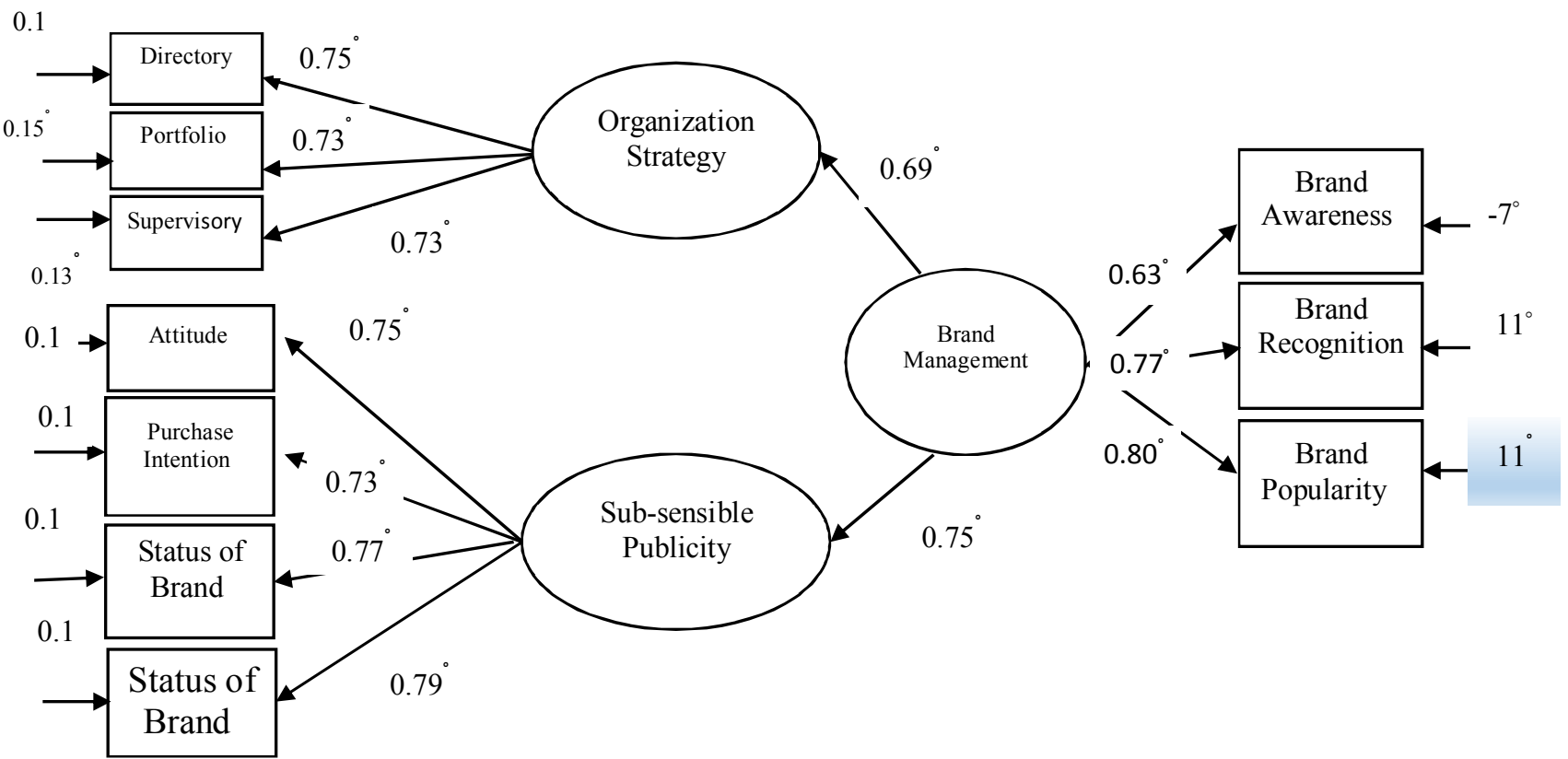

Fig. 3. Conceptual Investigation LAZERL Software

$\left({ }^{\circ}\right.$ represents meaningfulness of related coefficients) 


\section{Discussion and Conclusion}

According to the output of LAZERL Software, it indicates that there was a meaningful relationship between the research variables and all dimensions of brand management, organization strategy and sub-sensible advertisement have meaningful contributions in the model. Chi-Square value is equal to 30.06 with $\mathrm{df}=22$ and P-value $=0.000$. In addition, Root Mean Square Error of Approximation (RMSEA), Goodness of fit index (GFI), Adjusted Goodness of fit index (AGFI) are equal to 0.07, 0.95 and 0.91 and they are well above the desirable levels. Because of the positive coefficient of the relationship between the two research variables, we can say that the advertisement has a positive effect on improvement of brand management. Relation between organization strategy and brand management is also direct. The most primary principle in brand management is to create a picture to be able to motivate customers effectively and largely encourage their needs to use the bank's services. The brand management takes place properly when all communicative and advertising activities (as promised) being in line and coordinated with what would ultimately be provided for stakeholders. When a bank selects an advertising motto, it should be compatible with what its customers get in reality.

In order to conduct a perfect and sound brand management in a bank, it is necessary for the brand management officials to answer these questions by investigating a marketing policy:

- Who are our customers?

- What kind of services do we have to provide?

- How can we forestall our competitors?

- What resources and potentialities do we need to realize our banking services?

In fact, banks will access to most market share if they implement the brand management, and it is a key to achieve profit-making. For this reason, investment on a brand will count the one of premier strategies of an organization; according to the study results, it is essential to consider clandestine advertisement in an organization's investments and planning and to benefit the results significantly.

\section{References}

Aaker, D. A., \& Joachimsthaler, E. (2009). Brand leadership: Building assets in an information economy. Simon and Schuster.

Ariely, D., \& Berns, G. S. (2010). Neuromarketing: the hope and hype of neuroimaging in business. Nature Reviews Neuroscience, 11(4), 284-292.

Anderson, J. R., \& Bower, G. H. (2014). Human associative memory. Psychology press.

Dutka, S., \& Colley, R. (1995). DAGMAR, defining advertising goals for measured advertising results. NTC Business Books.

Davenport, T., \& Linder, J. (1994, January). Information management infrastructure: the new competitive weapon?. In System Sciences, 1994. Proceedings of the Twenty-Seventh Hawaii International Conference on (Vol. 4, pp. 885-896). IEEE.

Espejel, J., Fandos, C., \& Flavian, C. (2008). Consumer satisfaction: A key factor of consumer loyalty and buying intention of a PDO food product. British Food Journal, 110(9), 865-881.

Fournier, S. (1998). Consumers and their brands: developing relationship theory in consumer research. Journal of Consumer Research, 24(4), 343-353.

Henderson, J. C., \& Venkatraman, N. (1993). Strategic alignment: Leveraging information technology for transforming organizations. IBM Systems Journal, 32(1), 4-16.

Jafar Pisheh, Lh. (2011). Secret of Name and Making Sign, Amoukhteh Publication, ${ }^{\text {st }}$ ed., Esfahan, ISBN 976-600-6465-02-9. 
Keller, K. L., Parameswaran, M. G., \& Jacob, I. (2011). Strategic brand management: Building, measuring, and managing brand equity. Pearson Education India.

King, W. R., Grover, V., \& Hufnagel, E. H. (1989). Using information and information technology for sustainable competitive advantage: some empirical evidence. Information \& Management, 17(2), 87-93.

Kotler, P. (2009). Marketing management: A south Asian perspective. Pearson Education India.

Lee, C. W., \& Liao, C. S. (2009). The effects of consumer preferences and perceptions of Chinese tea beverages on brand positioning strategies. British Food Journal, 111(1), 80-96.

Molkaraei, N., (2013), Strategic management and its necessity to use in the course of sanctions. Editorial, Registered Accountant Magazine, 52.

Moore, T. E. (1982). Subliminal advertising: What you see is what you get. The Journal of Marketing, 46(2), 38-47.

Onkvisit, S., \& Shaw, J. J. (2004). International marketing: Analysis and strategy. Psychology Press.

Rossiter, J. R., \& Percy, L. (1987). Advertising and promotion management. McGraw-Hill Book Company.

Radder, L., \& Huang, W. (2008). High-involvement and low-involvement products: a comparison of brand awareness among students at a South African university. Journal of Fashion Marketing and Management, 12(2), 232-243.

Ross, J., \& Harradine, R. (2004). I'm not wearing that!: Branding and young children. Journal of Fashion Marketing and Management, 8(1), 11-26.

Scherer, F. M., \& Ross, D. (1990). Industrial market structure and economic performance. University of Illinois at Urbana-Champaign's Academy for Entrepreneurial Leadership Historical Research Reference in Entrepreneurship.

Theus, K. T. (1994). Subliminal advertising and the psychology of processing unconscious stimuli: A review of research. Psychology \& Marketing, 11(3), 271-290.

Ti-appey, C. (1996). A meta-analysis of consumer choice and subliminal advertising. Sychology and Marketing, 13, 517-30.

Trout, J., \& Ries, A. (2000). Positioning: The battle for your mind. Replay Radio, Radio New Zealand.

Zanot, E. J., Pincus, J. D., \& Lamp, E. J. (1983). Public perceptions of subliminal advertising. Journal of Advertising, 12(1), 39-45. 